\title{
IMPACTS OF ENVIRONMENTAL VARIABLES ON MACROINVERTEBRATE FUNCTIONAL FEEDING GROUPS AND BIODIVERSITY IN A MULING RIVER WETLAND FROM NORTHEAST CHINA
}

\author{
Sun, X. ${ }^{1 \#}-$ CHAI, F. Y. $.^{2 \#}-$ YU, H. X. ${ }^{3}-$ ZHANG, Y. ${ }^{4}-$ BAO, X. X. ${ }^{5}-$ LIU, M. H. $.^{3 *}-$ WANG, W. ${ }^{1 *}$ \\ ${ }^{1}$ College of Fisheries and Life Science, Dalian Ocean University, Dalian 116023, Liaoning \\ Province, China
}

${ }^{2}$ School of Management, Heilongjiang University of Science and Technology, Harbin 150020, Heilongjiang Province, China

${ }^{3}$ College of Wildlife and Protected Area, Northeast Forestry University, Harbin 150040, Heilongjiang Province, China

${ }^{4}$ NO.11 Middle School of Mudanjiang, Mudanjiang 157005, Heilongjiang Province, China

${ }^{5}$ Liuzhou High School, Liuzhou 157005, Guangxi Zhuang Autonomous Region, China

${ }^{\#}$ Co-first authors

These authors contributed to the work equally.

${ }^{*}$ Corresponding authors

e-mail: manhong@nefu.edu.cn (Liu, M. H.);wangwei@dlou.edu.cn (Wang, W.)

(Received $6^{\text {th }}$ May 2021; accepted $29^{\text {th }}$ Jul 2021)

\begin{abstract}
Muling River is the fifth-largest river in Heilongiiang Province, and it is also the main feeding river to the Ussuri River which is the boundary river of China and Russia in Heilongjiang Province northeast China. The Muling River basin is in the south of Sanjiang Plain. Macroinvertebrate samples were collected using a D-frame net and Shannon-Wiener index was calculated in terms of abundance. A total of 158 genera or species macroinvertebrates were collected from the 28 sampling sites and classified into six functional feeding groups including 61 gatherers / collectors, 42 predators, 22 scrapers, 14 shredders, 11 filterers / collectors and 8 omnivores. The correlation and relationship between environmental variables and macroinvertebrate functional feeding groups were explored using Pearson analysis and redundancy analysis. Temperature was associated with macroinvertebrates abundance, and nutrients were the main influence factors in Muling River basin.
\end{abstract}

Keywords: Muling River basin, macroinvertebrate, community structure, influencing factors, RDA

\section{Introduction}

Functions of river ecosystem research mostly carried out based on the traditional classification of species. However, recent studies have shown that ecosystem functions are mainly subject to the diversity of functional traits, i.e. the distribution of functional traits and the spatial-temporal pattern of abundance (Elliott and Quintino, 2010). Functional traits are sensitive to environmental changes and play a key role in the study of the relationship between biodiversity and ecosystem functions. Functional diversity based on biological traits is closely related to ecosystem processes and is the key to understand ecosystem and community functions (Jiang et al., 2018). Macroinvertebrates were widely used to monitor the damage of aquatic ecosystem, and they are also an 
important part of aquatic food web, which is the basis of nutrient cycle and ecological balance of ecosystem (Mangadze et al., 2016). Many factors have caused damage to the aquatic ecosystem in the Muling River basin, and the importance of monitoring water quality in the Muling River basin through macroinvertebrate is self-evident. The species characteristics of functional groups are more closely related to the environment, which can more directly reflect the ecological process of the ecological environment affecting aquatic communities, and better understand the water ecosystem and its biodiversity (An et al., 2017; Liu et al., 2019). In the river ecosystem, the functional diversity of macroinvertebrate can better reflect the ecosystem functions than community structure. Many studies have shown that substrate type and aquatic vascular plants are affecting the growth and functional group distribution of macroinvertebrate (Hubler et al., 2016; Ding et al., 2017; Kaskela et al., 2017).

Muling River is the fifth-largest river in Heilongjiang Province, and it is also the main feeding river to the Ussuri River which is the boundary river of China and Russia (Li et al., 2016). The approximately length of the Muling River is $834 \mathrm{~km}$ with annual water flows of 2.35 billion $\mathrm{m}^{3}$. The river flows through five counties or cities of Muling, Jixi, Jidong, Mishan and Hulin from the south to the northeast of Heilongjiang Province (Li et al., 2015). Upstream of the river is characterized by temperate continental climate with a hot summer rainy and long cold winter. The annual average precipitation in the upstream is $530 \mathrm{~mm}$ and mainly occurs from July to September. In the midstream, the climate is temperate and semi-humid monsoonal with annual average temperature of $3.1^{\circ} \mathrm{C}\left(-18^{\circ} \mathrm{C}\right.$ $\sim 21^{\circ} \mathrm{C}$ ). The annual precipitation is $522 \mathrm{~mm}$ and the frost-free period is 149 days. At downstream area, the climate is characterized by temperate continental monsoonal. In recent years, with the aggravation of agricultural non-point source pollution, industrial discharge pollution and urban living pollution in Muling River Basin, the water quality of Muling River is deteriorating, which has had a negative impact on the local people's production and life.

This study aimed to collect macroinvertebrate fauna, and explore the relationships between macroinvertebrate functional feeding groups and environmental variables in the wetland environments of Muling River basin.

\section{Materials and methods}

\section{Study area}

Muling River basin located in the south of Sanjiang Plain with an area of $18427 \mathrm{~km}^{2}$, and it is the fifth-largest river in Heilongjiang Province northeast of China, which is the main feeding river to the Ussuri River the boundary river of China and Russia (Fig. 1). According to the manual of inland waters fishery natural resources investigation (Zhang and He, 1991), and principles to the requirement of sampling sites, in combination with climatic characteristics and natural form of Muling River basin, 28 sampling sites were selected from upstream, midstream to downstream (Table 1).

\section{Environmental variables data sampling}

Samples were collected 3 times from 28 sampling sites of Muling River basin in May (spring), July (summer) and September (autumn) periods in 2015. Water transparency (SD) and water depth (WD) were measured in the field using a Secchi disk and graduated portable staff gauge, respectively. Electric conductivity (EC), dissolved oxygen (DO), pH 


$$
\text { - } 3993 \text { - }
$$

and water temperature (T) also measured in the field using a portable multi-probe (YSI 6600, YSI Inc., USA). We used the Chinese standard methods proposed by Ministry of Environmental Protection of People's Republic of China (Standard, 2002) to determine the concentration of total nitrogen $(\mathrm{TN})$, total phosphorus $(\mathrm{TP}), \mathrm{N}: \mathrm{P}$ ratio $(\mathrm{N}: \mathrm{P})$, ammonium nitrogen $\left(\mathrm{NH}_{4}{ }^{+}-\mathrm{N}\right)$, nitrate nitrogen $\left(\mathrm{NO}_{3}{ }^{-}-\mathrm{N}\right)$, chemical oxygen demand $\left(\mathrm{COD}_{\mathrm{Mn}}\right)$.
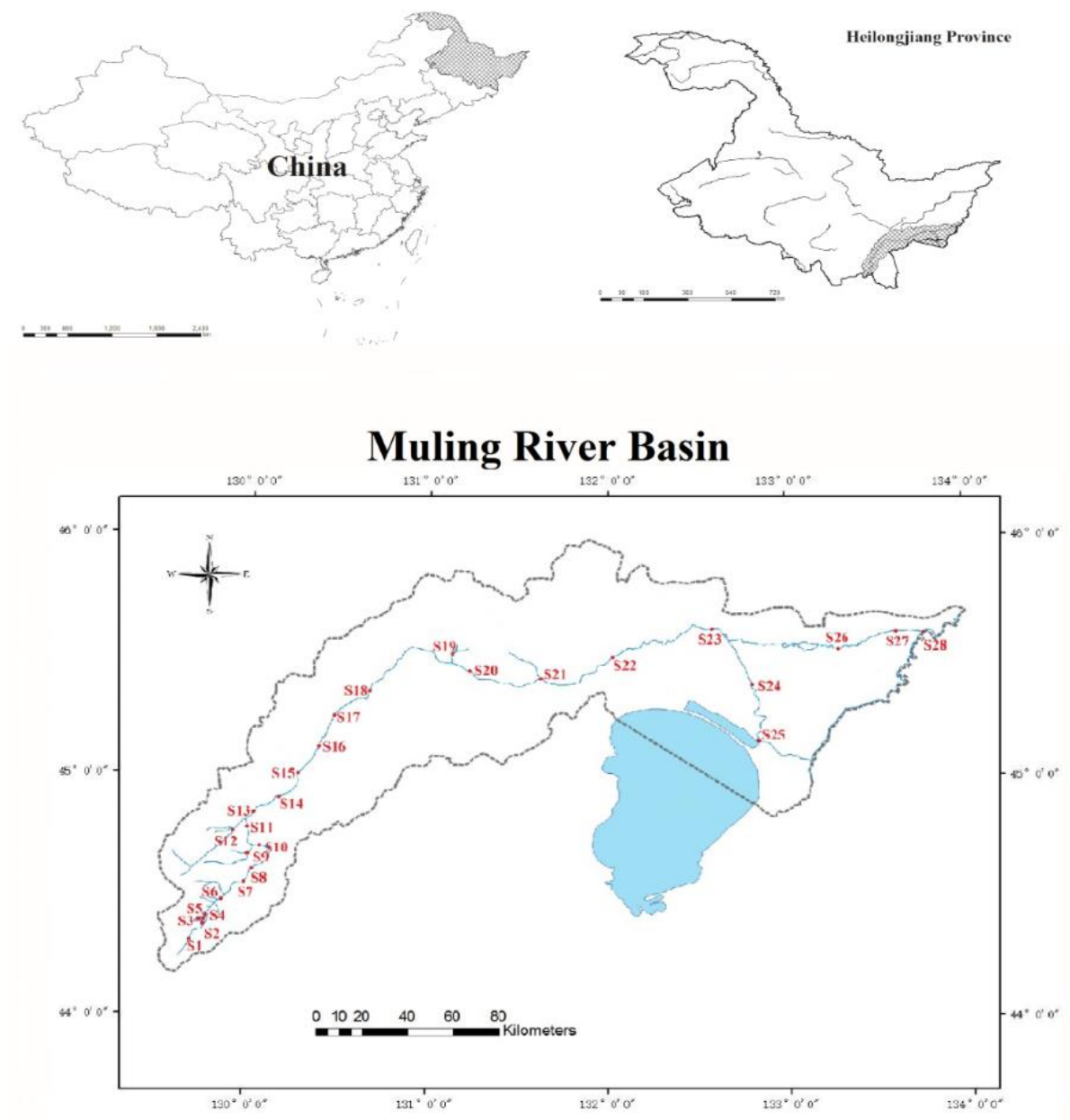

Figure 1. Location of 28 sampling sites in Muling River basin

\section{Macroinvertebrate data sampling}

Three random subsamples were collected at locations of $1 \mathrm{~m}^{2}$ at each sampling site by using a D-frame net $(0.25-\mathrm{mm}, 60 \mathrm{mesh})$. All macroinvertebrate samples were composited into a single sample, preserved in $75 \%$ ethanol and transported to the laboratory for identification. In the laboratory, all samples were sorted on white porcelain pans, identified, and counted with a light stereomicroscope $(10 \times$, Leica Microsystems, German). All individuals were identified to genus or species using appropriate identification guides (Morse et al., 1994; Epler, 2001). Taxa were divided into six functional feeding groups according to Cummins (1974) and Duan et al. (2010): predators (PR), omnivores (OM), gatherers/collectors (GC), filterers/collectors (FC), scrapers (SC) and shredders (SH) (Cummins, 1974; Duan et al., 2010). 
Table 1. The sampling stations and coordinates in Muling River basin

\begin{tabular}{c|c|c}
\hline Sampling sites & Latitude (N) & Longitude (E) \\
\hline S1 & $44^{\circ} 01^{\prime} 48^{\prime \prime}$ & $130^{\circ} 11^{\prime} 24^{\prime \prime}$ \\
S2 & $44^{\circ} 03^{\prime} 36^{\prime \prime}$ & $130^{\circ} 10^{\prime} 48^{\prime \prime}$ \\
S3 & $44^{\circ} 03^{\prime} 00^{\prime \prime}$ & $130^{\circ} 09^{\prime} 36^{\prime \prime}$ \\
S4 & $44^{\circ} 04^{\prime} 12^{\prime \prime}$ & $130^{\circ} 10^{\prime} 48^{\prime \prime}$ \\
S5 & $44^{\circ} 04^{\prime} 48^{\prime \prime}$ & $130^{\circ} 10^{\prime} 48^{\prime \prime}$ \\
S6 & $44^{\circ} 11^{\prime} 24^{\prime \prime}$ & $130^{\circ} 15^{\prime} 36^{\prime \prime}$ \\
S7 & $44^{\circ} 13^{\prime} 12^{\prime \prime}$ & $130^{\circ} 15^{\prime} 00^{\prime \prime}$ \\
S8 & $44^{\circ} 13^{\prime} 48^{\prime \prime}$ & $130^{\circ} 15^{\prime} 36^{\prime \prime}$ \\
S9 & $44^{\circ} 21^{\prime} 36^{\prime \prime}$ & $130^{\circ} 16^{\prime} 48^{\prime \prime}$ \\
S10 & $44^{\circ} 24^{\prime} 36^{\prime \prime}$ & $130^{\circ} 19^{\prime} 12^{\prime \prime}$ \\
S11 & $44^{\circ} 28^{\prime} 12^{\prime \prime}$ & $130^{\circ} 14^{\prime} 24^{\prime \prime}$ \\
S12 & $44^{\circ} 28^{\prime} 12^{\prime \prime}$ & $130^{\circ} 12^{\prime} 36^{\prime \prime}$ \\
S13 & $44^{\circ} 29^{\prime} 24^{\prime \prime}$ & $130^{\circ} 13^{\prime} 48^{\prime \prime}$ \\
S14 & $44^{\circ} 34^{\prime} 48^{\prime \prime}$ & $130^{\circ} 19^{\prime} 48^{\prime \prime}$ \\
S15 & $44^{\circ} 40^{\prime} 12^{\prime \prime}$ & $130^{\circ} 26^{\prime} 24^{\prime \prime}$ \\
S16 & $44^{\circ} 53^{\prime} 24^{\prime \prime}$ & $130^{\circ} 30^{\prime} 36^{\prime \prime}$ \\
S17 & $45^{\circ} 00^{\prime} 00^{\prime \prime}$ & $130^{\circ} 32^{\prime} 24^{\prime \prime}$ \\
S18 & $45^{\circ} 04^{\prime} 48^{\prime \prime}$ & $130^{\circ} 40^{\prime} 12^{\prime \prime}$ \\
S19 & $45^{\circ} 18^{\prime} 00^{\prime \prime}$ & $131^{\circ} 00^{\prime} 36^{\prime \prime}$ \\
S20 & $45^{\circ} 18^{\prime} 00^{\prime \prime}$ & $131^{\circ} 03^{\prime} 36^{\prime \prime}$ \\
S21 & $45^{\circ} 20^{\prime} 24^{\prime \prime}$ & $131^{\circ} 31^{\prime} 48^{\prime \prime}$ \\
S22 & $45^{\circ} 27^{\prime} 00^{\prime \prime}$ & $131^{\circ} 52^{\prime} 12^{\prime \prime}$ \\
S23 & $45^{\circ} 42^{\prime} 00^{\prime \prime}$ & $132^{\circ} 25^{\prime} 12^{\prime \prime}$ \\
S24 & $45^{\circ} 35^{\prime} 24^{\prime \prime}$ & $132^{\circ} 36^{\prime} 36^{\prime \prime}$ \\
S25 & $45^{\circ} 19^{\prime} 48^{\prime \prime}$ & $132^{\circ} 48^{\prime} 36^{\prime \prime}$ \\
S26 & $45^{\circ} 44^{\prime} 24^{\prime \prime}$ & $132^{\circ} 57^{\prime} 00^{\prime \prime}$ \\
S27 & $45^{\circ} 45^{\prime} 36^{\prime \prime}$ & $133^{\circ} 06^{\prime} 00^{\prime \prime}$ \\
S28 & $45^{\circ} 58^{\prime} 12^{\prime \prime}$ & $133^{\circ} 40^{\prime} 12^{\prime \prime}$ \\
\hline
\end{tabular}

\section{Statistical analyses}

Variation of environmental variables and abundance of functional groups in different sampling periods were analyzed using One-way ANOVA in SPSS 19.0 software. Before analysis, the data was $\lg (\mathrm{x}+1)$ transformed to manage variance heterogeneity and ensure the data is normally distributed. In this study, the gradient length of the first ordination axis was 0.404 in the detrended correspondence analysis (DCA). Therefore, redundancy analysis (RDA) with Monte Carlo simulations (499 permutations) ordination based on unimodal method was selected to analyze the relation by using CANOCO for Windows 4.5 software (Microcomputer Power, New York, USA). Pearson correlation analysis was carried out to confirm the significant relationships between environmental variables and the abundance of functional feeding group. Cluster analyses was conducted using the PRIMER 7 software package (Clarke and Gorley, 2015).

Diversity of macroinvertebrate FFGs was represented by Shannon-Wiener index (Shannon and Wiener, 1949) as follows:

$$
H^{\prime}=-\sum_{i=1}^{s} P_{i} \log _{2} P_{i}
$$

where, $S$ is the number of FFGs within the given sample; and $P_{i}$ is the percentage of FFGs $i$ in the total number of individuals. 


\section{Results}

\section{Environmental variables}

Among all sampling sties, natural gradients (e.g., dissolved oxygen and temperature) and nutrient indicators (e.g., total phosphorus, N:P ratio, ammonium nitrogen and nitrate nitrogen) were not significantly different $(p>0.05)$, but water transparency, water depth, electric conductivity, total nitrogen and chemical oxygen demand were significantly different $(p<0.01)$ (Table 2).

Table 2. One-Way ANOVA of environmental variables and macroinvertebrate FFGs abundance. Data are average values (with SE). Environmental variables: water transparency $(S D)$, water depth (WD), electric conductivity (EC), dissolved oxygen (DO), pH, water temperature (T), total nitrogen (TN), total phosphorus (TP), $N: P$ ratio (N:P), ammonium nitrogen $\left(\mathrm{NH}_{4}{ }^{+}-\mathrm{N}\right)$, nitrate nitrogen $\left(\mathrm{NO}_{3}{ }^{-} \mathrm{N}\right)$, chemical oxygen demand $\left(\mathrm{COD}_{\mathrm{Mn}}\right)$. Macroinvertebrate FFGs: predators (PR), omnivores (OM), gatherers/collectors (GC), filterers/collectors (FC), scrapers (SC) and shredders (SH). F-value and P-value from Oneway ANOVA by post-hoc test using Tukey HSD ANOVA

\begin{tabular}{|c|c|c|c|c|c|}
\hline & 2015May & 2015Jul. & 2015Sep. & $F$ & $p$-value \\
\hline \multicolumn{6}{|l|}{ Environmental variables } \\
\hline $\mathrm{SD}(\mathrm{m})$ & $0.35(0.05)$ & $0.32(0.07)$ & $0.48(0.07)$ & 10.418 & $0.000 * *$ \\
\hline $\mathrm{WD}(\mathrm{m})$ & $2.72(0.76)$ & $3.13(1.04)$ & $3.02(1.04)$ & 75.232 & $0.000 * *$ \\
\hline $\mathrm{EC}(\mathrm{ms} / \mathrm{cm})$ & $0.15(0.01)$ & $0.15(0.01)$ & $0.21(0.02)$ & 2.472 & $0.002 * *$ \\
\hline $\mathrm{DO}(\mathrm{mg} / \mathrm{L})$ & $7.45(0.29)$ & $8.73(0.29)$ & $7.49(0.56)$ & 1.676 & 0.052 \\
\hline $\mathrm{pH}$ & $7.42(0.12)$ & $7.03(0.26)$ & $7.99(0.06)$ & 1.903 & $0.021 *$ \\
\hline $\mathrm{T}\left({ }^{\circ} \mathrm{C}\right)$ & $14.81(0.47)$ & $22.26(0.55)$ & $6.89(0.43)$ & 0.215 & 0.862 \\
\hline $\mathrm{TN}(\mathrm{mg} / \mathrm{L})$ & $1.73(0.14)$ & $1.99(0.21)$ & $1.62(0.16)$ & 2.662 & $0.001 * *$ \\
\hline $\mathrm{TP}(\mathrm{mg} / \mathrm{L})$ & $0.6(0.05)$ & $0.69(0.04)$ & $0.36(0.03)$ & 0.456 & 0.986 \\
\hline $\mathrm{N}: \mathrm{P}$ & $3.86(0.56)$ & $3.13(0.35)$ & $6.56(1.6)$ & 0.727 & 0.815 \\
\hline $\mathrm{NH}_{4}{ }^{+}-\mathrm{N}(\mathrm{mg} / \mathrm{L})$ & $0.22(0.02)$ & $0.35(0.04)$ & $0.13(0.01)$ & 0.704 & 0.839 \\
\hline $\mathrm{NO}_{3}-\mathrm{N}(\mathrm{mg} / \mathrm{L})$ & $0.58(0.07)$ & $1.52(0.5)$ & $0.28(0.03)$ & 1.143 & 0.329 \\
\hline $\mathrm{COD}_{\mathrm{Mn}}(\mathrm{mg} / \mathrm{L})$ & $3.8(0.13)$ & $3.98(0.1)$ & $4.06(0.12)$ & 3.410 & $0.000 * *$ \\
\hline \multicolumn{6}{|l|}{ FFGs abundance } \\
\hline PR (ind./m²) & $25.75(3.47)$ & $46.75(2.68)$ & $24.54(2.6)$ & 0.614 & 0.916 \\
\hline $\mathrm{OM}$ (ind. $\left./ \mathrm{m}^{2}\right)$ & $12.14(3.03)$ & $5.68(0.85)$ & $5.82(1.1)$ & 0.701 & 0.842 \\
\hline GC (ind. $/ \mathrm{m}^{2}$ ) & $60.14(5.94)$ & $114.54(6.51)$ & $36.46(2.92)$ & 0.351 & 0.998 \\
\hline FC (ind. $\left./ \mathrm{m}^{2}\right)$ & $10.93(2.6)$ & $11.86(2.02)$ & $6.5(1.22)$ & 1.615 & 0.065 \\
\hline $\mathrm{SC}\left(\right.$ ind. $\left./ \mathrm{m}^{2}\right)$ & $38.93(12.36)$ & $30.46(4.67)$ & $17.75(2.22)$ & 2.335 & $0.004 * *$ \\
\hline SH (ind./m²) & $6.68(1.66)$ & $16.5(2.11)$ & $11.54(2.62)$ & 0.754 & 0.787 \\
\hline Total (ind./m²) & $154.57(14.29)$ & $225.79(8.52)$ & $102.61(6.2)$ & 0.535 & 0.946 \\
\hline Shannon-Wiener $\left(H^{\prime}\right)$ & $1.69(0.06)$ & $1.85(0.04)$ & $2.03(0.04)$ & 0.566 & 0.961 \\
\hline
\end{tabular}

$* P<0.05, * * P<0.01$

\section{Macroinvertebrate functional feeding groups}

During the sampling periods, a total of 13523 macroinvertebrate individuals belonging to 46 families 158 genera or species were identified from the study area, consisting of 61 gatherers/collectors, 42 predators, 22 scrapers, 14 shredders, 11 filterers/collectors and 8 omnivores (Appendix A). All FFGs, total abundance and Shannon-Wiener index were not significantly different $(p>0.05)$, while SC group was significantly different $(p<0.01)$ (Table 1, Fig. 2). Highest abundance of total macroinvertebrate was observed in summer, while the maximum value of Shannon-Wiener index presented in autumn (Fig. 3). 


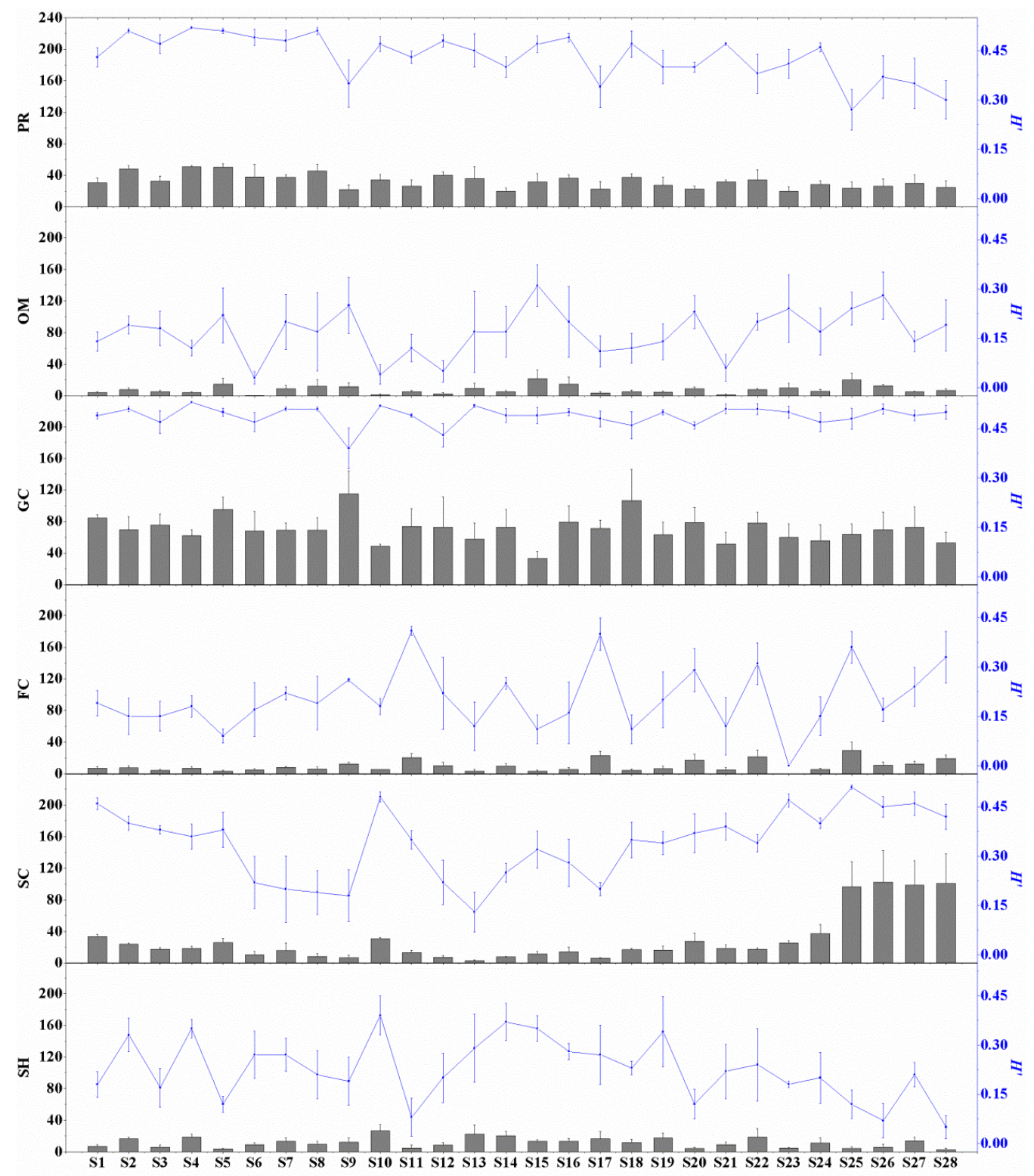

Figure 2. Macroinvertebrate FFGs abundance (ind. $/ \mathrm{m}^{2}$ ) among sampling sites. Macroinvertebrate FFGs: predators (PR), omnivores (OM), gatherers/collectors (GC), filterers/collectors $(F C)$, scrapers $(\mathrm{SC})$ and shredders $(\mathrm{SH})$

\section{Correlation analysis}

Correlation analysis indicated that temperature was associated with all FFGs abundance $(p<0.01$ or $p<0.05)$. By contrast, SD was negative significantly correlated with group FC $(p<0.05)$ and SH $(p<0.05)$ and DO displayed negative correlations with group PR $(p<0.05)$ and $\mathrm{SH}(p<0.01)$. The $\mathrm{pH}$ value negatively correlated with group GC $(p<0.01)$ and SC $(p<0.01)$. However, WD, TN, TP and $\mathrm{NH}_{4}{ }^{+}-\mathrm{N}$ were only positive significantly correlated with one group, such as PR $(p<0.05)$, $\mathrm{SH}(p<0.01)$ and GC $(p<0.01)$, respectively. While $\mathrm{N}: \mathrm{P}$ ratio was negative significantly correlated with group $\mathrm{GC}(p<0.05)$. CODMn positively correlated with group PR $(p<0.01)$ and $\mathrm{SH}(p<0.01)$ and negatively correlated with group SC $(p<0.05)$. 

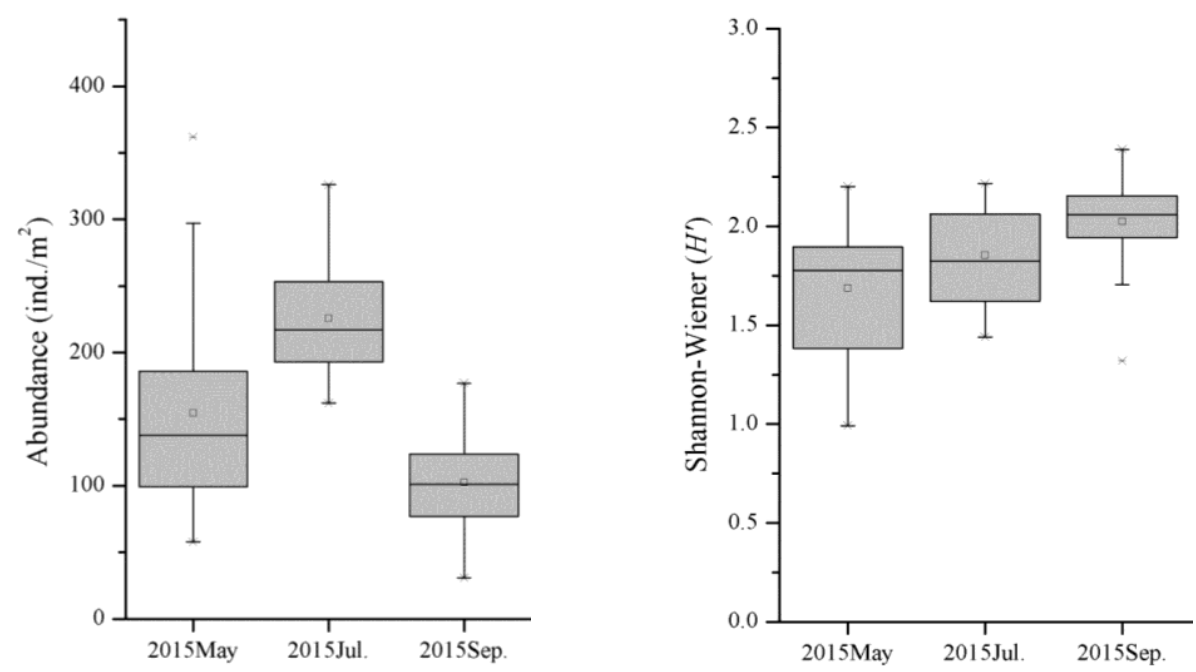

Figure 3. Boxplots of macroinvertebrate abundance and Shannon-Wiener index among seasons

On the other hand, environmental variables of $\mathrm{WD}, \mathrm{DO}$ and $\mathrm{N}: \mathrm{P}$ positively correlated with biodiversity index $\left(H^{\prime}\right)$ of $\mathrm{PR}, \mathrm{SH}$ and GC groups, respectively. TP was both negatively correlated with group GC and SC biodiversity index. COD $\mathrm{Mn}$ was positively correlated with group PR biodiversity index, while negatively correlated with group OM (Table 3).

Table 3. Correlation (Pearson) analysis between functional feeding groups abundance (ind. $\left./ m^{2}\right)$, Shannon-Wiener index $\left(H^{\prime}\right)$ and environmental variables. Some variables without any significant correlation were not shown. Environmental variables: water transparency $(S D)$, water depth $(W D)$, electric conductivity (EC), dissolved oxygen (DO), $p H$, water temperature (T), total nitrogen (TN), total phosphorus (TP), N:P ratio (N:P), ammonium nitrogen $\left(\mathrm{NH}_{4}^{+}-\mathrm{N}\right)$, nitrate nitrogen $\left(\mathrm{NO}_{3}-\mathrm{N}\right)$, chemical oxygen demand $\left(\mathrm{COD}_{\mathrm{Mn}}\right)$. Macroinvertebrate FFGs: predators (PR), omnivores (OM), gatherers/collectors (GC), filterers/collectors $(F C)$, scrapers $(S C)$ and shredders $(\mathrm{SH})$

\begin{tabular}{|c|c|c|c|c|c|c|c|c|c|c|c|}
\hline & \multicolumn{6}{|c|}{ Abundance } & \multicolumn{5}{|c|}{$H^{\prime}$} \\
\hline & PR & $\mathbf{O M}$ & GC & FC & SC & SH & PR & $\mathbf{O M}$ & GC & SC & SH \\
\hline $\begin{array}{l}\text { SD } \\
\text { WD }\end{array}$ & $0.153^{*}$ & & & $-0.162 *$ & & $-0.153^{*}$ & $0.220^{*}$ & & & & \\
\hline DO & $-0.162 *$ & & & & & $-0.223 * *$ & & & & & $0.260^{*}$ \\
\hline $\mathrm{pH}$ & & & $-0.343^{* *}$ & & $-0.218^{* *}$ & & & & & & \\
\hline $\begin{array}{c}\mathrm{T} \\
\mathrm{TN}\end{array}$ & $0.477 * *$ & $0.255^{* *}$ & $0.562 * *$ & $0.303 * *$ & $0.211 * *$ & $0.319^{* *}$ & & & & & \\
\hline $\mathrm{TP}$ & & & $0.271 * *$ & & & (0.J35) & & & $-0.224 *$ & $-0.230 *$ & \\
\hline $\mathrm{N}: \mathrm{P}$ & & & $-0.155^{*}$ & & & & & & $0.228 *$ & & \\
\hline $\mathrm{NH}_{4}^{+}-\mathrm{N}$ & & & & & $0.214 * *$ & & & & & & \\
\hline $\mathrm{COD}_{\mathrm{Mn}}$ & $0.242 * *$ & & & & $-0.202 * *$ & $0.280 * *$ & $0.274 *$ & $-0.218^{*}$ & & & \\
\hline
\end{tabular}

$* P<0.05, * * P<0.01$

\section{RDA analysis}

Redundancy analysis (RDA) revealed clear clusters of sampling sites by macroinvertebrate abundance and environmental variables (Fig. 4), with several outliers (S2, S25 and S28). The results of Monte Carlo test revealed that the first canonical axis 
and all canonical axes were significantly different $(\mathrm{F}=13.781, \mathrm{p}=0.002 ; \mathrm{F}=2.247$, $\mathrm{p}=0.004$, respectively), indicating associations between macroinvertebrate FFGs and environmental variables existed. The first two axes of FFGs correlations to environmental variables were 0.91 and 0.761 , which combined explained $87.4 \%$ of FFGs-environment relationship. In RDA biplot, TN and N:P had high inflation factors. Group SC and OM mainly impacted by $\mathrm{T}$ and $\mathrm{NH}_{4}{ }^{+}-\mathrm{N}$ at $\mathrm{S} 26$ and $\mathrm{S} 27$, and group $\mathrm{GC}$ and PR positively correlated with EC, WD and SD at S3, S4, S5, S20 and S24. Meanwhile, group SH has a positive correlation with TN, N:P and $\mathrm{NO}_{3}{ }^{-}-\mathrm{N}$ at S6, S15, S21, S22 and S23. We also found that $\mathrm{pH}, \mathrm{DO}$ and $\mathrm{COD}_{\mathrm{Mn}}$ were the main factors at S7 S14, S16, S17 and S19.

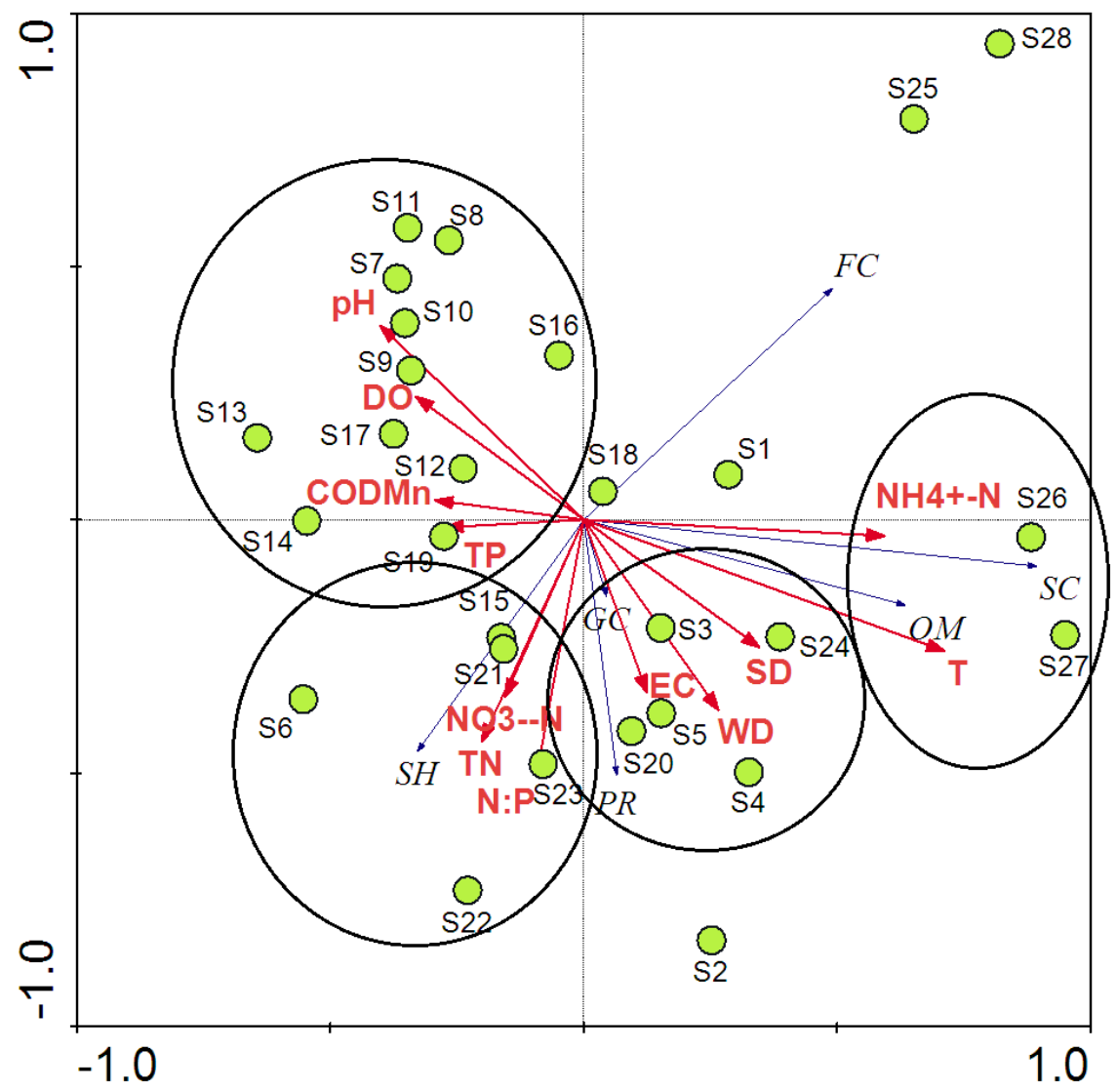

Figure 4. RDA biplot of macroinvertebrate FFGs abundance and environmental variables with sampling sites in Muling River basin. Environmental variables: water transparency (SD), water depth (WD), electric conductivity (EC), dissolved oxygen (DO), $p H$, water temperature (T), total nitrogen (TN), total phosphorus (TP), $N: P$ ratio $(N: P)$, ammonium nitrogen $\left(\mathrm{NH}_{4}{ }^{+}-\mathrm{N}\right)$, nitrate nitrogen $\left(\mathrm{NO}_{3}^{-}-\mathrm{N}\right)$, chemical oxygen demand $\left(\mathrm{COD}_{\mathrm{Mn}}\right)$. Macroinvertebrate FFGs: predators $(P R)$, omnivores $(O M)$, gatherers/collectors $(G C)$, filterers/collectors $(F C)$, scrapers $(S C)$ and shredders $(\mathrm{SH})$

\section{Discussion}

Functional groups can respond to changes in living environment and have a certain impact on ecosystem functions (Jia and Du, 2014). The difference of abundance is the result of habitat filtering, that is, the rank character with higher abundance can be considered as the character with better adaptability to regional environment (Menezes et al., 2010). Ecosystem function is essentially dependent on the functional group of the 
species, and which has become a powerful and reliable method to study the dynamic change of community by functional characters (Hooper and Vitousek, 1997; Diaz et al., 2004; Jiang et al., 2008). The large difference in spatial pattern of functional groups is the response to environmental changes and the tradeoff between different functions.

Globally, changes in land use, especially loss of riparian forests, can lead to a reduction or change in the structure, function and diversity of macroinvertebrate in some river basin (Allan, 2004; Benstead and Pringle, 2004; Jinggut et al., 2012). Once the riparian zone lacks the shelter of riverside forest, the sun will direct to the water surface and cause the water temperature to rise. Because the water temperature is close to the heat-resistant limit in tropical areas, some species of macroinvertebrate adapted to cold water cannot survive (Irons et al., 1994; Boyero et al., 2012). Moreover, the decrease of leaf litter is the main food source of shredders, which will block the growth and development of group $\mathrm{SH}$ and make the aquatic ecosystem unbalanced, and ultimately affect the structure and function of the ecosystem (Liu et al., 2019). Serious soil erosion in Muling River Basin, soil and water loss in riparian zones causes large amounts of sediment to enter rivers. The surface of river sediment is covered by muddy soil, which affects the growth of algae (Jia et al., 2009; Jiang et al., 2018). At the same time, these sediments will also adhere to the surface of the body, trachea, and gill of the macroinvertebrate, which leading to the disappearance of macroinvertebrate (Magbanua et al., 2013).

In this study, we demonstrated the impacts of environmental variables on macroinvertebrate feeding functional groups. No significant differences in the FFGs were observed along season gradient, except group SC (Table 1). Mollusk (group SC) dominated at sampling sites of S25 S28 in the downstream of river, which close to floodplain wetlands along Ussuri River. Guan et al. (2017) sampled macroinvertebrate assemblages along Wusuli River (upstream, midstream, and downstream), and agreed with the emerging theory suggesting that aquatic invertebrate assemblages in floodplain wetlands should change longitudinally along a river's length and be affected by lateral connectivity of floodplain habitats with main river channels (Guan et al., 2017). Wu et al. (2017) found that snails could be possess several attributes that should make them useful as potential environmental indicators in Sanjiang Plain, and the certain snail species may provide a robust and rapid indicator of environmental impacts in freshwater in Heilongjiang Province of China (Wu et al., 2017). Next year, Guan et al. (2018) also confirmed that the snails (Mollusca: Gastropoda) can rapid assessments of wetland condition using aquatic invertebrates simple effective in northeastern China (Guan et al., 2018).

Macroinvertebrate community structure is usually determined by the physical structure and complexity of the habitat (Rennie and Jackson, 2005). Aquatic vascular plants play an important role in structuring macroinvertebrate species and selecting species related to functional groups dynamics and feeding habits (Valinoti et al., 2011; Gleason et al., 2018). The distribution of macroinvertebrate is also determined by vegetation type, especially the structure and growth form of aquatic vascular plants (Rennie and Jackson, 2005). Aquatic vascular plants affect the underwater climate and chemical properties by absorbing and releasing chemical substances (such as nutrients and antagonistic substances) (Valk and Arnold, 2010). However, as the growth of aquatic vascular plants in northern China is mainly affected by seasonal temperature changes, dominant communities can only be formed in summer and autumn (Liu et al., 2019).

In spring, the farmland near the Muling River basin contains a lot of nutrients (nitrogen and phosphorus) in the sediment of pesticide and chemical fertilizers. Chen et al. (2019) 
studies have shown that nitrogen can enter the water body through fish secretion and excretion (Chen et al., 2019). Nitrogen-containing nutrients in the water body are absorbed by algae growth and carried down together through surface runoff to provide sufficient nutrients for the growth of plankton. Meanwhile, greatly increased the number of plankton which as the source of food for macroinvertebrate, such as group $\mathrm{SH}$ positively correlated with TN (Table 2 ).

Moreover, iron, as an element affecting chlorophyll synthesis in plants, is also a trace element needed for phytoplankton growth (Zhang, 2015). Trace element copper is an indispensable metal element for the metabolism of microelements and plants in cell membranes, which can affect the growth of plankton (Zhang et al., 2014). Hydrology is considered the paramount environmental control of freshwater wetlands, with temporary drying being a major constraint on aquatic insects (Wu et al., 2019). The movement group (Liu et al., 2019) of macroinvertebrate could be considered as a new method for monitoring and evaluating water quality in Muling River basin for further studies in the future.

\section{Conclusions}

During the three times sampling in Muling River basin, we collected 13523 macroinvertebrate individuals belonging to 46 families 158 genera or species were identified from the study area, consisting of 61 gatherers/collectors, 42 predators, 22 scrapers, 14 shredders, 11 filterers/collectors and 8 omnivores. All FFGs, total abundance and Shannon-Wiener index were not significantly different. Total abundance of macroinvertebrate was higher in summer and biodiversity index was higher in autumn. We found that temperature was associated with all FFGs abundance and nutrients were the main influence factors in Muling River basin. Therefore, controlling the input of nutrients is the key to the ecological environment and aquatic biodiversity protection of the Muling River basin in the future.

Acknowledgements. This study was supported by The central government supports the reform and development fund projects of local colleges and universities "Research on integrated technology innovation of sustainable utilization of cold water fish resources industrialization" (2020GSP14), and Key research topics of economic and social development in Heilongjiang Province (20309). Liaoning science and technology major special plan "Liaoning important marine fish efficient green production mode research and development and demonstration" project (2020JH1/10200002), Dalian Science and Technology Innovation Fund Project (2019J12SN64), and Agricultural finance special project "Investigation of fishery resources and environment in key waters of Northeast China". The authors are grateful to the people that helped with all aspects of the fieldwork.

\section{REFERENCES}

[1] Allan, J. D. (2004): Landscapes and riverscapes: the influence of land use on stream ecosystems. - Annual Review of Ecology, Evolution and Systematics 35(1): 257-284.

[2] An, R., Wang, F. Y., Yu, H. X., Ma, C. X. (2017): Seasonal dynamics of zooplankton functional groups and their relationships with environmental factors in the Sanhuanpao wetland reserve. - Acta Ecologica Sinica 37(6): 1851-1860. (in Chinese with English abstract).

[3] Benstead, J. P., Pringle, C. M. (2004): Deforestation alters the resource base and biomass of endemic stream insects in eastern Madagascar. - Freshwater Ecol 49(4): 490-501. 
[4] Boyero, L., Pearson, R. G., Dudgeon, D. (2012): Global patterns of stream detritivore distribution: implications for biodiversity loss in changing climates. - Glo. Ecol. and Biogeo. 21(2): 134-141.

[5] Chen, L. L., Gao, Y. X., Zhang, Y. M., Zhu, Y. M., Kong, M., Xu, X. T., Wang, Y. T., Huang, T. Y. (2019): Effects of Plagiogathops micrloepis Bleeker, Hypophthalmichthys molitrix and Aristichthys nobilis polyculture on water environment and nitrogen migration and transformation. - China Environ. Sci. 39(3): 1181-1188. (in Chinese with English abstract).

[6] Clarke, K. R., Gorley, R. N. (2015): PRIMER v7 user manual/tutorial. - In: PRIMER-E, Plymouth.

[7] Cummins, K. W. (1974): Structure and function of stream ecosystems. - Bio Science 24: 631-641.

[8] Diaz, S., Hodgson, J. G., Thompson, K., Cabido, M., Zak, M. R. (2004): The plant traits that drive ecosystems: evidence from three continents. - Journal of Vegetation Science 15(3): 295-304.

[9] Ding, N., Yang, W., Zhou, Y., González-Bergonzoni, I., Zhang, J., Chen, K., Vidal, N., Jeppesen, E., Liu, Z., Wang, B. (2017): Different responses of functional traits and diversity of stream Zoobenthos to environmental and spatial factors in the Xishuangbanna watershed of the upper Mekong River Basin, China. - Sci. of The Tot. Envir. 574: 288-299.

[10] Duan, X. H., Wang, Z. Y., Xu, M. Z. (2010): Benthic Zoobenthos and Application in the Assessment of Stream Ecology. - Tsinghua University Press, Beijing.

[11] Elliott, M., Quintino, V. (2010): Benthic Zoobenthos and Application in the Assessment of Stream Ecology. - Tsinghua University Press, Beijing.

[12] Epler, J. H. (2001): Identification manual for the larval chironomidae (Diptera) of North and South Carolina. - Grant \# X984170-97. America: EPA.

[13] Gleason, J. E., Bortolotti, Y. J., Rooney, C. R. (2018): Wetland microhabitats support distinct communities of aquatic Zoobenthos. - J. of Freshwater Ecol. 33(1): 73-82.

[14] Guan, Q., Wu, H., Lu, K., Lu, X., Batzer, D. (2017): Longitudinal and lateral variation in snail assemblages along a floodplain continuum. - Hydrobiologia 792(1): 1-12.

[15] Guan, Q., Liu, J., Batzer, D. P., Lu, X., Wu, H. (2018): Snails (Mollusca: Gastropoda) as potential surrogates of overall aquatic invertebrate assemblage in wetlands of Northeastern China. - Ecol. Indic. 90: 193-200.

[16] Hooper, D. U., Vitousek, P. M. (1997): The effects of plant composition and diversity on ecosystem processes. - Science 277(5330): 1302-1305.

[17] Hubler, S., Huff, D. D., Edwards, P., Pan, Y. (2016): The Biological Sediment Tolerance Index: Assessing fine sediments conditions in Oregon streams using Zoobenthos. - Ecol. Ind. 67: 132-145.

[18] Irons, J. G., Oswood, M. W., Stout, R. J., Pringle, C. M. (1994): Latitudinal patterns in leaf litter breakdown: is temperature really important? - Freshwater Biol. 32(2): 401-411.

[19] Jia, X. H., Jiang, W. X., Li, F. Q., Tang, T., Duan, S. G., Cai, Q. H. (2009): The response of benthic algae to the impact of acid mine drainage. - Acta Ecologica Sinica 29(9): 46204629. (in Chinese with English abstract).

[20] Jia, P., Du, G. Z. (2014): Measuring functional and phylogenetic diversity in community ecology. - Chin. Bull. of Life Sci. 26(02): 153-157. (in Chinese with English abstract).

[21] Jiang, W. X., Tang, T., Jia, X. H., Wu, N. C., Duan, S. G., Li, D. F., Cai, Q. H. (2008): Impacts of acid pyrite drainage on the Zoobenthos community in Gaolan River. - Acta Ecologica Sinica 28(10): 4805-4814. (in Chinese with English abstract).

[22] Jiang, W. X., Chen, J., Wang, H. M., He, S. S., Zhou, L. L., Chen, Q., Wang, H. K., Cai, Q. H. (2018): Study of Zoobenthos functional traits and diversity among typical habitats in the New Xue River. - Acta Ecologica Sinica 38(6): 2007-2016. (in Chinese with English abstract). 
[23] Jinggut, T., Yule, C. M., Boyero, L. (2012): Stream ecosystem integrity is impaired by logging and shifting agriculture in a global megadiversity center (Sarawak, Borneo). - Sci. of the Tot. Environ. 437(20): 83-90.

[24] Kaskela, A. M., Rousi, H., Ronkainen, M., Orlova, M., Babin, A., Gogoberidze, G., Kostamo, K., Kotilainen, A. T., Neevin, I., Ryabchuk, D., Sergeev, A., Zhamoida, V. (2017): Linkages between benthic assemblages and physical environmental factors: the role of geodiversity in Eastern Gulf of Finland ecosystems. - Cont. Shelf Res. 142: 1-13.

[25] Li, J. M., Yu, T., Ju, Y. F., Chai, F. Y., Yu, H. X. (2015): Assessment methods of water environment quality-a case study of Muling River. - J. of Anhui Agri. Sci. 43(27): 185188. (in Chinese with English abstract).

[26] Li, J. M., Lu, L. K., Yu, P., Liu, M. Q., Wei, S. H., Chai, F. Y., Yu, T., Chai, Q. Y., Ju, Y. F., Yu, H. X. (2016): Analysis of water quality of Muling River from 2010 to 2014. Wetland sci. 14(2): 226-229. (in Chinese with English abstract).

[27] Liu, M. H., Meng, Y., Cao, J. J., Cui, X. B., Al, M. N. (2019): Functional traits of Zoobenthos in Naolihe Wetland. - J Northeast Fore Univ. 47(1): 76-82. (in Chinese with English abstract).

[28] Magbanua, F. S., Townsend, C. R., Hageman, K. J., Matthaei, C. D. (2013): Individual and combined effects of fine sediment and the herbicide glyphosate on benthic Zoobenthos and stream ecosystem function. - Freshwater Biol. 58(8): 1729-1744.

[29] Mangadze, T., Bere, T., Mwedzi, T. (2016): Choice of biota in stream assessment and monitoring programs in tropical streams: a comparison of diatoms, Zoobenthos and fish. Ecol. Indic. 63(4): 128-143.

[30] Menezes, S., Baird, D. J., Amvm, S. (2010): Beyond taxonomy: a review of Zoobenthos trait-based community descriptors as tools for freshwater biomonitoring. - J. of App. Eco. 47(7): 711-719.

[31] Morse, J. C., Yang, L. F., Tian, L. X. (1994): Aquatic Insects of China Useful for Monitoring Water Quality. - Nanjing: Hohai University Press.

[32] Rennie, M. D., Jackson, L. J. (2005): The influence of habitat complexity on littoral invertebrate distributions: patterns differ in shallow prairie lakes with and without fish. Canadian Journal of Fisheries and Aquatic Sciences 62(9): 2088-2099.

[33] Shannon, C. E., Wiener, W. (1949): The mathematical theory of communication. - Urbana: University of Illinois Press.

[34] Standard (2002): Standard Methods for the Analysis of Water and Wastewater, Fourth ed. - Ministry of Environmental Protection of the People's Republic of China, Beijing.

[35] Valinoti, E., Ho, C. K., Armitage, A. R. (2011): Native and exotic submerged aquatic vegetation provide different nutritional and refuge values for Zoobenthos. - J. Exp. Mar. Biol Ecol. 409: 42-47.

[36] Valk, V. D., Arnold, G. (2010): The biology of freshwater wetlands. - Freshwater Biology 52(2): 397-397.

[37] Wu, H. T., Guan, Q., Lu, X., Batzer, D. P. (2017): Snail (Mollusca: Gastropoda) assemblages as indicators of ecological condition in freshwater wetlands of Northeastern China. - Ecol. Indic. 75: 203-209.

[38] Wu, H. T., Guan, Q., Lu, K. L., Batzer, D. P. (2019): Aquatic Zoobenthos assemblages in wetlands of Northeastern China. - Hydrobiologia 838(1): 153-162.

[39] Zhang, J. M., He, Z. H. (1991): Neilu Yuye Ziran Ziyuan Diaocha Shou Ce. - Beijing: China Agriculture Press. (in Chinese with English abstract).

[40] Zhang, G. X., Wu, Z. J., Chen, S. Q., Cai, Z. F., Wang, D. R. (2014): The ecological characteristics of zooplankton and the relationship among environmental factors in the Sanya Bay in spring. - J. of Fisheries Research 36(3): 176-184. (in Chinese with English abstract).

[41] Zhang, Y. Y. (2015): Experimental study on the effects of light and the concentration of iron on phytoplankton growth of small Xingkai Lake. - Harbin: Northeast Forestry University. (in Chinese with English abstract). 


$$
-4003-
$$

\section{APPENDIX}

Appendix A. Macroinvertebrate community structure and functional feeding groups during the sampling periods. Symbols: relative abundance $+(<1 \%),++(1-1.9 \%),+++(>2 \%)$

\begin{tabular}{|c|c|c|c|c|c|}
\hline Family & Genera or species & FFGs & 2015 May & 2015 July & 2015 Sep. \\
\hline \multirow[t]{4}{*}{ Corixidae } & Corixa substriata & PR & ++ & ++ & + \\
\hline & Hesperocoixa distani & PR & & + & \\
\hline & Hesperocorixa kirkaldy & PR & + & & \\
\hline & Sigra distanti & PR & & + & \\
\hline \multirow[t]{4}{*}{ Tipulidae } & Hexatoma sp. & PR & + & & \\
\hline & Nippotipula sp. & $\mathrm{SH}$ & + & ++ & +++ \\
\hline & Erioptera sp. & GC & + & + & + \\
\hline & Pilaria sp. & PR & & + & \\
\hline \multirow[t]{33}{*}{ Chironomidae } & Diplocladius sp. & GC & ++ & ++ & + \\
\hline & Heterotrissocladius sp. & GC & & + & \\
\hline & Eukiefferiella fuldensis & $\mathrm{GC}$ & & + & \\
\hline & Synorthocladius semivirens & GC & & ++ & \\
\hline & Orthocladius roussellae & $\mathrm{GC}$ & & + & \\
\hline & Orthocladius sp. & GC & & + & + \\
\hline & Orrhocladius thienemanni & GC & & + & \\
\hline & Orrhocladius vaillanti & GC & & +++ & \\
\hline & Thienemannia gracilis & GC & + & + & ++ \\
\hline & Chironomus kiiensisTokunaga & GC & +++ & +++ & ++ \\
\hline & Chironomus flaviplumus & $\mathrm{GC}$ & +++ & + & + \\
\hline & Chironomus dorsalis & GC & & ++ & \\
\hline & Chaetocladius sp. & GC & & ++ & \\
\hline & Chironomus plumosus & $\mathrm{OM}$ & + & + & ++ \\
\hline & $\begin{array}{c}\text { Cryptochironomus } \\
\text { maculipennis }\end{array}$ & PR & ++ & ++ & + \\
\hline & Parachironomus arcnatus & PR & + & ++ & + \\
\hline & Eukiefferiella fittkaui & GC & ++ & +++ & ++ \\
\hline & Eukiefferiella fuldensis & GC & + & ++ & + \\
\hline & Eukiefferiella sp. & $\mathrm{GC}$ & & ++ & \\
\hline & Eukiefferiella gracei & $\mathrm{GC}$ & & + & \\
\hline & Parakiefferiella $\mathrm{sp}$ & GC & & + & + \\
\hline & Dicrotendipes nigrocephalicus & GC & ++ & ++ & \\
\hline & Dicrotendipes pelochloris & GC & ++ & +++ & + \\
\hline & Dicrotendipes tamaviridis & GC & ++ & + & \\
\hline & Dicrotendipus lobifer & GC & & ++ & \\
\hline & Smittia $\mathrm{sp}$ & GC & +++ & ++ & + \\
\hline & Pseudosmittia sp.1 & GC & + & & + \\
\hline & Pseudosmittia sp.2 & GC & & + & ++ \\
\hline & Polypedilum nubeculosum & $\mathrm{SH}$ & + & + & \\
\hline & Polypedilum laetum & $\mathrm{SH}$ & + & ++ & \\
\hline & Polypedilum sordens & $\mathrm{SH}$ & + & + & ++ \\
\hline & Polypedilum scalaenum & $\mathrm{SH}$ & & + & \\
\hline & Polypedilum nubifer & $\mathrm{SH}$ & & & \\
\hline
\end{tabular}




\begin{tabular}{|c|c|c|c|c|c|}
\hline Family & Genera or species & FFGs & 2015 May & 2015 July & 2015 Sep. \\
\hline & Cricotopus vierriensis & $\mathrm{SH}$ & & & +++ \\
\hline & Cricotopus bicinctus & SH & & & + \\
\hline & Zalutschia sp. & SH & & + & \\
\hline & Apsectrotanypus sp. & PR & +++ & + & ++ \\
\hline & Glyptotendipes pallens & FC & & + & \\
\hline & Glyptotendipes gripekoveni & $\mathrm{FC}$ & & + & \\
\hline & Glyptotendipes tokunagai & $\mathrm{FC}$ & & + & \\
\hline & Stictochironomus maculipennis & $\mathrm{OM}$ & + & & + \\
\hline & Stictochironomus akizukii & $\mathrm{OM}$ & +++ & + & + \\
\hline & Stictochironomus sp.A. & $\mathrm{OM}$ & +++ & + & ++ \\
\hline & Stictochironomus sp.B. & $\mathrm{OM}$ & + & + & + \\
\hline & Stictochironomus caffrarius & $\mathrm{OM}$ & & & \\
\hline & Paracladopelma undine & GC & + & + & + \\
\hline & Paracladopelma nigritula & GC & + & + & + \\
\hline & Chironomus anthracinus & $\mathrm{GC}$ & ++ & + & ++ \\
\hline & Harnischia fuscimana & $\mathrm{GC}$ & ++ & + & \\
\hline & Micropsectra chuzeprima & GC & + & + & ++ \\
\hline & Tanypus sp. & PR & & + & +++ \\
\hline & Tanypus villipennis & PR & + & + & \\
\hline & Cladotanytarsus vanderwulpi & GC & & + & \\
\hline & Tanytarsus mendex & FC & + & + & ++ \\
\hline & Tanytarsus chinyensis & FC & +++ & + & + \\
\hline & Tanytarsus signatus & $\mathrm{FC}$ & + & & \\
\hline Ephemeridae & Ephemera shengmi & GC & + & + & \\
\hline & Ephemera nigroptera & GC & + & & \\
\hline Heptageniidae & Heptagenia sp. & $\mathrm{SC}$ & ++ & + & \\
\hline Ephemerelliae & Ephemerella nigra & GC & + & + & \\
\hline & Ephemerellidae serratella & GC & & + & \\
\hline & Ephemerella fusongensis & $\mathrm{GC}$ & + & & \\
\hline Baetidae & Baetis sp. & $\mathrm{GC}$ & + & + & \\
\hline & Baetis thermicus & GC & & + & \\
\hline Leptophlebiidae & Leptophlebia sp. & $\mathrm{GC}$ & & + & \\
\hline & Paraleptophlebia sp. & GC & & + & \\
\hline & Thraulus sp. & GC & & + & \\
\hline Siphlonuridae & Ameletus montanus & GC & & + & \\
\hline Potamanthidae & Potamanthidae sp. & GC & + & & \\
\hline Chloroperlidae & Alloperla sapporoensis & PR & + & + & \\
\hline & Alloperla nikkoensis & PR & + & & \\
\hline Pteronarcyidae & Pteronarys sp. & PR & & + & \\
\hline Pelidae & Paragnetina sp. & PR & ++ & + & \\
\hline & Cyamia sp. & PR & + & + & \\
\hline & Agnetina sp. & PR & & + & \\
\hline Perlodidae & Hydroperla japonica & PR & & & \\
\hline Peltoperlidae & Perlomyer sp. & SH & + & + & \\
\hline Taeniopterygidae & Doddsia iaponica & SH & & + & \\
\hline Hydropsychidae & Hydropsyche sp. & $\mathrm{FC}$ & + & + & + \\
\hline
\end{tabular}




\begin{tabular}{|c|c|c|c|c|c|}
\hline Family & Genera or species & FFGs & 2015 May & 2015 July & 2015 Sep. \\
\hline & Hydropsyche nakaharai & $\mathrm{FC}$ & +++ & & \\
\hline Hydroptilldae & Hydroptila sp. & SC & + & + & + \\
\hline Polycentropodidae & Polycentropus sp. & FC & + & ++ & ++ \\
\hline \multirow[t]{2}{*}{ Goeridae } & Goera ramosa & SC & + & + & ++ \\
\hline & Goera kyotonis & $\mathrm{SC}$ & + & + & \\
\hline Stenopsychidae & Parastenopsyche sp. & GC & & + & \\
\hline Rhyacophilidae & Rhyacophila sp. & PR & + & + & \\
\hline \multirow[t]{5}{*}{ Limnephilidae } & Apatania sp. & $\mathrm{SC}$ & + & + & + \\
\hline & Neophylax sp. & SC & & ++ & +++ \\
\hline & Stenophylax koizumii & SH & & + & \\
\hline & Glyphotaelius admorsus & SH & ++ & & \\
\hline & Stenophylax koizumii & SH & + & & \\
\hline Libellulidae & Epiophcetia superstes & PR & + & + & ++ \\
\hline Petaluridae & Tanypteryx pryeri & PR & & + & ++ \\
\hline Macromiidae & Macromidae sp. & PR & & + & \\
\hline Libellulidae & Hydrobasileus sp. & PR & + & + & \\
\hline \multirow[t]{4}{*}{ Comphidae } & Davidius nanus & PR & & + & + \\
\hline & Cercion sieboldii & PR & & + & \\
\hline & Gomphus postocularis & PR & & & + \\
\hline & Ictinogomphus sp. & PR & & + & \\
\hline Gomphidae & Anisogomphus sp. & PR & + & + & \\
\hline Lestidae & Lestes sp. & PR & & + & \\
\hline \multirow[t]{2}{*}{ Agriidae } & Nenrobasis sp. & PR & & + & +++ \\
\hline & Calopteryx cornecia & PR & & & + \\
\hline Dytiscidae & Cybister japonicus & PR & + & + & + \\
\hline Noteridae & Noterus sp. & PR & & + & \\
\hline Carabidae & Chlaenius sp. & PR & & + & ++ \\
\hline Hydrophilidae & Hydrophilus acuminatus & PR & + & + & \\
\hline \multirow[t]{7}{*}{ Glossiphoniidae } & Helobdella nuda & PR & + & + & + \\
\hline & Batracobdella paludosa & PR & ++ & & + \\
\hline & Glossiphonia heteroclita & PR & ++ & + & + \\
\hline & Parabdella quadrioculata & PR & & + & + \\
\hline & Glossiphonia complanata & PR & & & \\
\hline & Glossiphonia lata & PR & & + & ++ \\
\hline & Whitmania sp. & PR & & + & ++ \\
\hline \multirow[t]{10}{*}{ Tubificinae } & Limnodrilus hoffmeisteri & GC & ++ & ++ & ++ \\
\hline & Limnodrilus claparedeianus & GC & + & + & ++ \\
\hline & Limnodrilus helveticus & GC & + & + & + \\
\hline & Limnodrilus udekemianus & GC & ++ & & \\
\hline & Limnodrilus amblysetus & GC & + & + & + \\
\hline & Aulodrilus bretscher & GC & & + & + \\
\hline & Aulodrilus pigueti & GC & & + & + \\
\hline & Branchiura sowerbyi & GC & ++ & + & + \\
\hline & Tubifex tubifex & GC & ++ & + & + \\
\hline & Spirosperma nikolskyi & GC & & + & +++ \\
\hline Enchytraeidae & Henlea sp. & $\mathrm{GC}$ & & + & \\
\hline
\end{tabular}




\begin{tabular}{|c|c|c|c|c|c|}
\hline Family & Genera or species & FFGs & 2015 May & 2015 July & 2015 Sep. \\
\hline \multirow[t]{5}{*}{ Naididae } & Nais variabilis & GC & ++ & + & + \\
\hline & Nais communis & $\mathrm{GC}$ & + & + & + \\
\hline & Nais simplex & GC & + & + & \\
\hline & Slavina sp. & GC & + & & + \\
\hline & Dero sp. & $\mathrm{GC}$ & + & & \\
\hline \multirow[t]{2}{*}{ Melaniidae } & Semisulcospira amurensis & $\mathrm{SC}$ & +++ & ++ & ++ \\
\hline & Semisulcospira cancellata & $\mathrm{SC}$ & ++ & + & + \\
\hline \multirow[t]{4}{*}{ Viviparidae } & Bellamya purrificata & $\mathrm{SC}$ & ++ & + & ++ \\
\hline & Viviparus chui & $\mathrm{SC}$ & + & + & + \\
\hline & Cipangopaludina Chinensis & $\mathrm{SC}$ & ++ & + & + \\
\hline & Cipangopaludina ussuriensis & $\mathrm{SC}$ & + & + & + \\
\hline Hydrobiidae & Parafossarulus striatus & SC & ++ & + & + \\
\hline \multirow[t]{8}{*}{ Lymnaeidae } & Lymnaea stagnalis & SC & ++ & + & + \\
\hline & Radix auricularia & $\mathrm{SC}$ & + & + & ++ \\
\hline & Radix plicatula & $\mathrm{SC}$ & + & + & + \\
\hline & Radix swinhoei & $\mathrm{SC}$ & ++ & + & + \\
\hline & Radix ovata & $\mathrm{SC}$ & ++ & + & + \\
\hline & Radix lagotis & $\mathrm{SC}$ & ++ & + & + \\
\hline & Galba pervia & $\mathrm{SC}$ & +++ & + & + \\
\hline & Galba truncatula & SC & + & + & + \\
\hline Planoribidae & Polypylis hemisphaerula & $\mathrm{SC}$ & ++ & + & + \\
\hline \multirow[t]{2}{*}{ Unionidae } & Unio douglasiae & FC & + & + & + \\
\hline & Lanceolaria grayana & $\mathrm{FC}$ & + & + & + \\
\hline \multirow[t]{2}{*}{ Palaemonidae } & Exopalaemon modestus & $\mathrm{OM}$ & + & + & + \\
\hline & Palaemon sinensis & $\mathrm{OM}$ & + & + & + \\
\hline
\end{tabular}

